\title{
ANTIOXIDANT ACTIVITY ASSESSMENT IN FRUIT LIQUORS AND SPIRITS: METHODS COMPARISON
}

\section{AVALIAÇÃO DA ATIVIDADE ANTIOXIDANTE EM LICORES DE FRUTOS E AGUARDENTES: COMPARAÇÃO DE MÉTODOS}

\author{
Carolina Santos $^{1}$, Goreti Botelho ${ }^{1,2 *}$, Ilda Caldeira ${ }^{3,4}$, Amílcar Torres ${ }^{5}$, Fernanda M. Ferreira ${ }^{6,7}$
}

\author{
${ }^{1}$ Department of Food Science and Technology, Coimbra College of Agriculture, Polytechnic Institute of Coimbra, Bencanta, 3045-601 Coimbra, \\ Portugal \\ ${ }^{2}$ CERNAS Research Unit, Coimbra College of Agriculture, Polytechnic Institute of Coimbra, Bencanta, 3045-601 Coimbra, Portugal \\ ${ }^{3}$ National Institute of Agricultural and Veterinary Research-INIAV, Dois Portos, Quinta da Almoínha, 2565-191 Dois Portos, Portugal \\ ${ }^{4}$ Institute of Mediterranean Agrarian and Environmental Sciences, University of Évora, Portugal \\ ${ }^{5}$ Department of Life Sciences, Faculty of Science and Technology, University of Coimbra, Coimbra, Portugal \\ ${ }^{6}$ Department of Environment, Coimbra College of Agriculture, Polytechnic Institute of Coimbra, Bencanta, 3045-601 Coimbra, Portugal \\ ${ }^{7}$ Center for Investigation and Agro Environmental and Biological. Technologies (CITAB) - UTAD, Quinta de Prados, Apartado 1013, 5001-801 \\ Vila Real, Portugal \\ * corresponding author: Goreti Botelho. Tel. +351 239802940, Fax +351 239802979, E-mail: goreti@esac.pt
}

(Received 16.05.2014. Accepted 30.05.2014)

\section{SUMMARY}

During the last few years, Portugal has seen an increasing trend in the development of new fruit-based products, such as liquors and spirits. The antioxidant capacity of fruit liquors and spirits, sourced commercially or produced on a pilot-scale, was assessed using two simple spectrophotometric methods: the 2,2'-azino-bis-(3-ethylbenzothiazoline-6-sulphonic acid) (ABTS) and 1,1-diphenyl-2-picrylhydrazyl (DPPH) assays. The major goal of this work was to find which of the two methods is the most suitable and accurate in determining antioxidant capacity for fruit liquors and spirits. In addition, the total phenolic compounds of both kinds of alcoholic beverages were determined by Folin-Ciocalteau method. Despite the widespread use of DPPH assay for distilled drinks, a weak Spearman correlation coefficient $(\mathrm{r}=0.023)$ between ABTS and DPPH methods in spirits were found, as well as, between DPPH values and total phenolic compounds content $(\mathrm{r}=0.239)$. This work highlights the limitations of DPPH assay when used for analysis of samples with very low antioxidant capacity, as distilled spirits.

\section{RESUMO}

Portugal, nos últimos anos, tem desenvolvido novos produtos à base de frutos, tais como aguardentes e licores. A capacidade antioxidante dos licores de frutos e aguardentes, obtidos comercialmente ou em produções à escala piloto, foi medida usando dois métodos espetrofotométricos: o 2,2'-azino-bis-(3-etilbenzotiazolina-6-ácido sulfónico) (ABTS) e o 1,1-difenil-2-picrilhidrazil (DPPH). O principal objetivo deste trabalho consistiu em determinar qual o método mais fiável na determinação da capacidade antioxidante total das aguardentes e licores. Adicionalmente, o conteúdo total em compostos fenólicos de ambos os tipos de bebidas alcoólicas foi determinado pelo método de Folin-Ciocalteau. Embora o DPPH seja o método mais utilizado neste tipo de análises, no presente trabalho, no entanto, verificou-se que o coeficiente de correlação de Spearman ( $\mathrm{r}=0.023$ ) entre o ABTS e DPPH é baixo, bem como entre os valores de DPPH e o teor de compostos fenólicos totais ( $\mathrm{r}=0.239$ ). Este trabalho destaca assim as limitações do método de DPPH quando usado em amostras com baixa capacidade antioxidante, como é o caso dos licores de frutos e das aguardentes.

Key words: fruit liquors and spirits, total antioxidant activity, ABTS, DPPH, total phenolic compounds.

Palavras-chave: licores de frutos e aguardentes, capacidade antioxidante total, ABTS, DPPH, compostos fenólicos totais.

\section{INTRODUCTION}

The production of distillates (spirits) from fermented fruits, as well as, fruit liquors has been widely practiced around the world, including Portugal, for several centuries.

There are several studies focused on the evaluation of total antioxidant compounds in fruits (Liu et al.,
2002; Céspedes et al., 2010; Huang et al., 2012). Antioxidant capacity is related to the ability to capture the free radicals, being an important defence mechanism of living systems, in opposition to oxidative stress (Valko et al., 2006; Oliveira et al., 2009). Abundant evidence suggests that oxidative stress is a major cause of aging and several chronic diseases, including cancer, diabetes, cardiovascular 
disease, Alzheimer's disease, and other neurodegenerative disorders (Halliwell, 1994; Giacco and Brownlee, 2011). Many antioxidant compounds, such as polyphenols, possess anti-inflammatory, antiatherosclerotic, antiproliferative, antimutagenic, anticarcinogenic, antibacterial, or antiviral activities to a greater or lesser extent (Liu et al., 2002; Ratnam et al., 2006).

During the production of alcoholic beverages from fruits or from fermented fruits, such as spirits or liquors, it will be expected that some antioxidant compounds, such as phenolic compounds, remain in these beverages (Mrvcic et al., 2012). Furthermore, aging in wooden barrels is a major source of phenolic compounds in alcoholic beverages, such as rum, wine, whiskey, brandy and "cachaça” (Mosedale and Puech, 1998; Goldberg et al., 1999; Arnous et al., 2001; Da Silva et al., 2009). These beverages have variable content of phenolic compounds that can be related to their antioxidant capacity (Vicente et al., 2011). In fact, the presence of low molecular weight phenolic compounds, such as vanillin, syringaldehyde, syringic acid, vanillic acid, gallic acid, coumarin, scopoletin and furanic compounds has been reported (Goldberg et al., 1999; Arnous et al., 2001; Madrera et al., 2003; De Aquino et al., 2006; Da Silva et al., 2009).

A wide range of spectrophotometric assays have been adopted to measure antioxidant capacity of food and the most popular alcoholic beverages, being the chemical methods using 2,2'-azino-bis-(3ethylbenzothiazoline-6-sulphonic acid) (ABTS) and 1,1-diphenyl-2-picrylhydrazyl (DPPH) assays the most commonly performed (Brand-Williams et al., 1995; Kim et al., 2002; Canas et al., 2008; Floegel et al., 2011).

Most of these chemical methods for determining antioxidant capacity employ the same principle: a synthetic coloured radical or redox-active compound is generated; and the ability of a biological sample to scavenge the radical or to reduce the redox-active compound is monitored using a UV-Vis, applying an appropriate standard to quantify antioxidant capacity. The approach is based on electron transfer and involves the reduction of a coloured oxidant, as $\mathrm{ABTS}^{\circ+}$ and $\mathrm{DPPH}^{\circ}$, which includes a change in colour that can be spectrophotometrically quantified (Brand-Williams et al., 1995; Kim et al., 2002). These easy and economic methods to evaluate radical scavenging activity of antioxidants, since the radical compounds are stable and need not be generated, are very convenient in their applications; nevertheless, they present several limitations, including the promiscuity of reactions of $\mathrm{ABTS}^{\circ+}$ and $\mathrm{DPPH}^{\circ}$ as they use non physiological radicals (Floegel et al., 2011). Also, $\mathrm{DPPH}^{*}$ is sensitive to some Lewis bases and solvent types, as well as, oxygen (Ancerewicz et al., 1998).

Generally, DPPH assay has been used to assess antioxidant capacity of spirits such as Cognac (Da
Porto et al., 2000), Portuguese brandies (Canas et al., 2008) and aged sugar cane spirits (Vicente et al., 2011).

As far as we know from the scientific literature, a performance comparison of ABTS and DPPH has not been, previously, assessed using fruit liquors and spirits in similar, but adjusted, experimental conditions. Hence, the major goal of this research was to compare the efficiency of ABTS and DPPH methods to evaluate the antioxidant capacities of fruit liquors and spirits. In addition, the total phenolic compounds of both categories of alcoholic beverages studied were determined.

\section{MATERIAL AND METHODS}

\section{Chemicals}

2,2'-azino-bis-(3-ethylbenzothiazoline-6-sulphonic acid) $\quad\left(\mathrm{ABTS}^{\circ+}\right), \quad$ 1,1-diphenyl-2-picrylhydrazyl (DPPH'), 6-hydroxy-2,5,7,8-tetramethylchroman-2carboxylic acid (Trolox), potassium persulfate and Folin-Ciocalteau reagent were obtained from SigmaAldrich (St. Louis, MO, USA). All the other chemicals used were of analytical grade.

\section{Samples}

The samples used in the assays are described in Table I. The ethanol content of spirits was determined by electronic densimetry (OIV, 2014) by using an electronic densimeter (Antoon Paar DMA 5000, 2002, Austria). The ethanol content of fruit liquors was determined by using an automatic distillerextractor apparatus (Dujardin-Salleron, DE 2000 model, 2004, France) followed by aerometry of the obtained distillates.

\section{Pilot-scale production of fruit spirits and liquors}

Spirits were obtained, separately, in a pilot-scale production. The distillation was performed in a 16 $\mathrm{dm}^{3}$ copper Charentais alembic. The first part with approximately 5\% (above $70 \%$ vol., with a strong, pungent and unpleasant flavour) of the distillates was collected as head fraction and was discarded. The heart fractions (spirits - Table I), obtained by single distillation, were collected when the ethanol concentration varied from 70 to $35 \% \mathrm{v} / \mathrm{v}$; finally, the tail fractions were obtained and discarded when the alcoholic content decreased below 35\% v/v. The alcoholic fermentation of each fruit occurred under controlled conditions. The wine spirits were obtained from red table wine of Marselan grape variety with 14 $\%$ vol.

Fruit liquors (Table I) were obtained, both from pilotscale production and commercial sources. The pilotscale production was done with maceration and extraction between each fruit (previously washed and cut in small slices) and wine spirit (previously adjusted to $45 \%$ vol.) without wood aging. 
TABLE I

Codification of fruit liquors and spirits

Codificação dos licores de fruto e das aguardentes

\begin{tabular}{llcc}
\hline Sample code & Description & Origin & Alcohol degree (\% vol.) \\
\hline Spirits & & & \\
\hline S1 & Wine spirit & Psp & 40.0 \\
S2 & Wine spirit & Psp & 55.0 \\
S3 & Apple & Psp & 40.0 \\
S4 & Persimmon & Psp & 49.8 \\
S5 & Fig & Psp & 44.9 \\
S6 & Fig & Psp & 44.3 \\
S7 & Cherry & Psp & 53.4 \\
S8 & Psp & 45.0 \\
S9 & Passionfruit & Psp & 37.6 \\
S10 & Pineapple with shell & Psp & 42.4 \\
S11 & Mango with shell & Psp & 42.0 \\
S12 & Mango shelled & Psp & 39.5 \\
S13 & Banana & Psp & 45.3 \\
S14 & Persimmon & Psp & 40.0 \\
S15 & Persimmon & Psp & 40.0 \\
\hline Fruit liquors & & & \\
\hline L1 & Green walnut & Psp & 18.5 \\
L2 & Green walnut & Psp & 18.5 \\
L3 & Green walnut & Psp & 18.1 \\
L4 & Green walnut & Psp & 18.1 \\
L5 & Fig & C & 17.0 \\
L6 & Carob & C & 17.0 \\
L7 & Carob & C & 20.0 \\
L8 & Passionfruit & C & 15.0 \\
L9 & Mulberry & C & 20.0 \\
\hline C = commercial source; Psp = Pilot-scale production & \multicolumn{2}{c}{}
\end{tabular}

\section{Determination of antioxidant activity}

\section{ABTS assay}

$\mathrm{ABTS}^{\circ+}$ radical-scavenging activity of the hydrophilic fractions was determined by a procedure reported by Miller and Rice-Evans (1997) with slight modifications. The $\mathrm{ABTS}^{\circ+}$ solution was prepared by mixing $7 \mathrm{mmol} . \mathrm{dm}^{-3}$ of ABTS salt with $3 \mathrm{mmol} . \mathrm{dm}^{-3}$ of potassium persulfate, and the final volume was adjusted to $25 \mathrm{~cm}^{3}$ with distilled water. The solution was held at room temperature, in the dark, for $16 \mathrm{~h}$ before use. The $\mathrm{ABTS}^{\circ+}$ solution was diluted with water, in order to obtain an absorbance between 0.680 and 0.720 at $734 \mathrm{~nm}$, using a Xion 500 spectrophotometer UV-Vis (Hach Lange, 2002, Germany). $\mathrm{ABTS}^{*+}$ solution was freshly prepared for each analysis. Antioxidant or standard solutions, 50 $\mu \mathrm{L}$ (corresponding to $2500 \mathrm{mg} \cdot \mathrm{dm}^{-3}$ ), were mixed with $1 \mathrm{~mL}$ of diluted $\mathrm{ABTS}^{\circ+}$ solution and incubated at $30{ }^{\circ} \mathrm{C}\left( \pm 1{ }^{\circ} \mathrm{C}\right)$ in a thermostatically-controlled water bath (Selecta, Precisterm 20L, 2008, Spain). The absorbance at $734 \mathrm{~nm}$ was read after 6 min under dim light conditions. Ethanol (95\%) was used as a blank. A standard curve was performed for each assay, using Trolox $\left(1 \mathrm{mmol} . \mathrm{dm}^{-3} ; 0150 \mu\right.$ mol. $\mathrm{dm}^{-3}$; $\left.\mathrm{R}^{2}>0.990\right)$. All experiments were performed three times and in triplicate at controlled temperature of 30 $\pm 1{ }^{\circ} \mathrm{C}$. The free-radical scavenging activity was expressed as micromoles of Trolox per milliliter of sample $\left(\mu \mathrm{mol} \mathrm{TE} . \mathrm{cm}^{-3}\right)$.

\section{DPPH assay}

The antioxidant activity of the samples and standard (Trolox) was determined by the radical scavenging activity method using 2,2-diphenyl-1-picrylhydrazyl radical (DPPH') as, previously described by BrandWilliams et al. (1995) with slight modifications. Briefly, $50 \mathrm{~mm}^{3}$ aliquots of samples were added to $1.95 \mathrm{~cm}^{3}$ of a DPPH ${ }^{*}$ methanolic solution $(0.4 \% \mathrm{~m} / \mathrm{v})$. The blank sample consisted of $50 \mathrm{~mm}^{3}$ of methanol added to $1.95 \mathrm{~cm}^{3}$ of $\mathrm{DPPH}^{\circ}$. After a $30 \mathrm{~min}$ incubation period at room temperature $\left(22.0 \pm 1.0^{\circ} \mathrm{C}\right)$ in the dark, the absorbance was measured at $517 \mathrm{~nm}$ (Sharma and Bhat, 2009), using a Xion 500 spectrophotometer UV-Vis (Hach Lange, 2002, Germany) under dim light conditions. A standard curve was performed for each assay, using Trolox (1 mmol. $\left.\mathrm{dm}^{-3} ; 0150 \mu \mathrm{mol} ; \mathrm{R}^{2}>0.990\right)$. All experiments were performed three times and in triplicate and the free-radical scavenging activity was expressed as micromoles of Trolox per milliliter of sample $(\mu \mathrm{mol}$ TE. $\mathrm{cm}^{-3}$ ).

\section{Phenolic compounds evaluation}

Total phenolic compounds were estimated by the Folin-Ciocalteau method, a colorimetric assay based on procedures described by Singleton and Rossi 
(1965). Briefly, $50 \mathrm{~mm}^{3}$ of sample was mixed with $0.95 \mathrm{~cm}^{3}$ of $7.5 \%$ sodium carbonate freshly prepared solution. After 30 seconds, $1 \mathrm{~cm}^{3}$ of Folin Ciocalteu's phenol reagent was added. The reaction was kept in the dark, with the reaction tubes place on a thermostatically-controlled water bath at $40 \pm 1.0^{\circ} \mathrm{C}$ for $30 \mathrm{~min}$. The absorbance was read using glass cuvettes, at $765 \mathrm{~nm}$, using a Xion 500 spectrophotometer UV-Vis (Hach Lange, 2002, Germany) under dim light conditions. Gallic acid (1 mmol. $\mathrm{dm}^{-3}$ ) was used as a standard to construct a standard curve (0 $\left.20 \mu \mathrm{mol} ; \mathrm{R}^{2} \geq 0.990\right)$ and $20 \mathrm{~mm}^{3}$ ethanol $95 \% \mathrm{~m} / \mathrm{v}$ was added to the blank $\left(30 \mathrm{~mm}^{3}\right.$ deionised water, mixed with $0.95 \mathrm{~cm}^{3}$ of $7.5 \%$ sodium carbonate and $1 \mathrm{~cm}^{3}$ of Folin Ciocalteu's phenol reagent added after $30 \mathrm{~s}$ ). All experiments were performed three times and in triplicate. Results were expressed as gallic acid equivalents per amount sample (GAE.cm ${ }^{-3}$ ).

\section{Statistics}

Results are presented as mean \pm SEM (standard error of the mean) of three independent experiments performed in triplicate. Spearman-Rho coefficients were calculated using the software IBM SPSS 20.0 (SPSS Inc., Chicago, IL, USA).

\section{RESULTS AND DISCUSSION}

The ethanol contents of the fifteen spirits showed values ranging from 37.6 to $55.0 \% \mathrm{v} / \mathrm{v}$ and all of them were above the legal limit level ( $\geq 37.5 \% \mathrm{v} / \mathrm{v})$. The ethanol contents of the nine fruit liquors showed values ranging from 15.0 to $20 \% \mathrm{v} / \mathrm{v}$ and all of them were above the legal limit level $(>15.0 \% \mathrm{v} / \mathrm{v})$ (Regulation EC n. 110/2008).

Most techniques used for determining antioxidant activity, such as, ABTS, DPPH, FRAP (ferric reducing ability of plasma) and ORAC (oxygen radical absorbance capacity) assays, showed high correlation with total phenolic content in different fruits (and plant extracts) (Dudonné et al., 2009; Floegel et al., 2011). Phenolic compounds, are the most abundant secondary metabolites in fruits, responsible for their antioxidant activity (Macheix et al., 1990). Also, high correlation between total phenolic content and antioxidant activity as determined by FRAP or electron spin resonance spectroscopy were reported in fruit juices (Gardner et al., 2000). In the present work, the samples used are made from fruit and were not wood aged, for this reason, their antioxidant activity and total phenolic content derive only from the fruits.

Armagnac, Cognac and other aged brandies are rich in phenolic compounds due to their maturation in wooden barrels (Viriot et al., 1993; Canas, 2003). DPPH method is commonly used to evaluate the antioxidant capacity of distilled drinks aged in wood (Da Porto et al., 2000; Aoshima et al., 2004). Nevertheless, it was verified that the use of this method in the present work for the evaluation of spirits antioxidant capacity was not successful, since samples with low amount of antioxidants and phenolic compounds assessed by Folin-Ciocalteau method (Singleton and Rossi, 1965) presented non detectable antioxidants using DPPH method (Table II).

\section{TABLE II}

Antioxidant capacity of spirits and their total phenolic content

Capacidade antioxidante e compostos fenólicos totais das aguardentes

\begin{tabular}{|c|c|c|c|}
\hline \multirow[b]{2}{*}{ Sample code } & \multicolumn{2}{|c|}{ Antioxidant capacity $\left(\mu \mathrm{mol}\right.$ TE.cm $\left.{ }^{-3}\right)$} & \multirow{2}{*}{$\begin{array}{l}\text { Total Phenolic Content } \\
\left(\mu \mathrm{mol} \text { Eq GAE.cm }{ }^{-3}\right)\end{array}$} \\
\hline & ABTS assay & DPPH assay & \\
\hline $\mathrm{S} 1$ & $959.4 \pm 42.5$ & n.d. & $556.4 \pm 32.8$ \\
\hline $\mathrm{S} 2$ & $989.8 \pm 127.4$ & n.d. & $489.0 \pm 3.2$ \\
\hline $\mathrm{S} 3$ & $97.6 \pm 2.5$ & n.d. & $193.7 \pm 6.6$ \\
\hline S4 & $50.2 \pm 2.3$ & n.d. & $72.3 \pm 4.8$ \\
\hline S5 & $359.4 \pm 10.6$ & n.d. & $365.7 \pm 8.0$ \\
\hline S6 & $88.6 \pm 4.0$ & n.d. & $164.5 \pm 8.2$ \\
\hline S7 & $80.1 \pm 2.9$ & n.d. & $199.6 \pm 8.8$ \\
\hline S8 & $199.3 \pm 13.6$ & n.d. & $250.1 \pm 7.2$ \\
\hline S9 & $139.5 \pm 17.7$ & n.d. & $250.2 \pm 6.2$ \\
\hline S10 & $290.0 \pm 4.6$ & n.d. & $419.1 \pm 7.1$ \\
\hline S11 & $154.4 \pm 12.4$ & n.d. & $441.4 \pm 3.4$ \\
\hline S12 & $221.3 \pm 11.2$ & n.d. & $195.2 \pm 4.0$ \\
\hline $\mathrm{S} 13$ & $185.9 \pm 13.6$ & n.d. & $216.0 \pm 5.2$ \\
\hline S14 & $70.1 \pm 3.9$ & n.d. & $57.1 \pm 4.1$ \\
\hline S15 & $71.4 \pm 4.4$ & n.d. & $39.6 \pm 0.9$ \\
\hline
\end{tabular}

Data are mean value \pm SEM; n.d. - not detected 
Since $\mathrm{pH}$ was maintained in the range of $5.0-6.5$ (Molyneux, 2004), its effects were discarded (Blois, 1958). Therefore, $\mathrm{pH}$ seemed not to influence the results achieved, conversely to some assays. This was not the first time we faced this problem with distilled spirits in our lab, so, we used different reagent sources for the different assessments and ethanol was used as the control without interference in the results obtained. Ascorbic acid was also used as standard; however due to its lability, the results were instead expressed in terms of Trolox equivalents (TE).

For fruit liquors containing a large content of phenolic compounds, the DPPH method detected antioxidant capacity with similar results to ABTS method (Table III). Nevertheless, the sample with lower content of phenolic compounds presented a non-detectable value for Trolox equivalents (L6, carob liquor with $17 \%$ ethanol (v/v), obtained commercially). Likewise, in all the samples analyzed - sourced commercially or produced in a pilot-scale the antioxidant activity evaluated with the DPPH method was not coherent with total phenolic content (Tables II and III). Therefore, a similar spectrophotometric method in which $\mathrm{ABTS}^{*+}$ is solubilized in distilled water was performed (Tables II and III).

TABLE III

Antioxidant capacity of fruit liquors and their total phenolic content

Capacidade antioxidante e compostos fenólicos totais dos licores de fruto

\begin{tabular}{|c|c|c|c|}
\hline \multirow[b]{2}{*}{ Sample code } & \multicolumn{2}{|c|}{ Antioxidant capacity ( $\mu \mathrm{mol}$ TE.cm $\left.{ }^{-3}\right)$} & \multirow{2}{*}{$\begin{array}{r}\text { Total Phenolic Content } \\
\left(\mu \mathrm{mol} \text { Eq GAE.cm }{ }^{-3}\right)\end{array}$} \\
\hline & ABTS assay & DPPH assay & \\
\hline L1 & $1285 \pm 23.6$ & $2371 \pm 72.6$ & $12800 \pm 41.24$ \\
\hline L2 & $1274 \pm 23.6$ & $2364 \pm 72.8$ & $12800 \pm 55.94$ \\
\hline L3 & $1275 \pm 23.5$ & $2395 \pm 77.8$ & $12800 \pm 40.76$ \\
\hline L4 & $1251 \pm 27.6$ & $2275 \pm 101.5$ & $12900 \pm 35.66$ \\
\hline L5 & $1272 \pm 24.0$ & n.d. & $12700 \pm 16.41$ \\
\hline L6 & $139.7 \pm 10.6$ & n.d. & $610 \pm 13.33$ \\
\hline L7 & $1307 \pm 24.3$ & $2543 \pm 35.4$ & $13200 \pm 19.72$ \\
\hline L8 & $1151 \pm 28.2$ & $659.7 \pm 89.3$ & $6900 \pm 14.48$ \\
\hline L9 & $1301 \pm 23.7$ & $2510 \pm 56.5$ & $13000 \pm 23.78$ \\
\hline
\end{tabular}

Data are mean value \pm SEM; n.d. - not detected.

Total phenolic content was correlated with antioxidant activity of fruit liquors and spirits and the Spearman-Rho coefficients were calculated (Tables IV and V).

\section{TABLE IV}

Spearman-Rho coefficients for the correlation between antioxidant capacities measured by ABTS, DPPH and total phenolic content of fifteen spirits

Coeficiente de correlação de Spearman-Rho entre a capacidade antioxidante obtida por ABTS, DPPH e compostos fenólicos totais em quinze aguardentes

\begin{tabular}{lrrr}
\hline & ABTS & DPPH & $\begin{array}{r}\text { Total Phenolic } \\
\text { Content }\end{array}$ \\
\hline ABTS & 1 & 0.023 & $0.448^{*}$ \\
DPPH & 0.023 & 1 & 0.239 \\
$\begin{array}{l}\text { Total Phenolic } \\
\text { Content }\end{array}$ & $0.448^{*}$ & 0.239 & 1 \\
\hline
\end{tabular}

* Correlation is significant at $\alpha<0.05$ (2-tailed).

Gorinstein et al. (2010) reported a high correlation between polyphenols content in three exotic fruits and antioxidant capacities measured by ABTS and DPPH assays. Dudonné et al. (2009) reported a strong positive correlation between ABTS and DPPH assays with a Pearson correlation coefficient of $r=0.906$ when used for 30 aqueous plant extracts.

TABLE V

Spearman-Rho coefficients for the correlation between antioxidant capacities measured by ABTS, DPPH and total phenolic content of nine fruit liquors

Coeficiente de correlação de Spearman-Rho entre a capacidade antioxidante obtida por ABTS, DPPH e compostos fenólicos totais em nove licores de fruto

\begin{tabular}{lrrr}
\hline & ABTS & DPPH & $\begin{array}{r}\text { Total Phenolic } \\
\text { Content }\end{array}$ \\
\hline ABTS & 1 & $0.883^{* *}$ & $0.814^{* *}$ \\
DPPH & $0.883^{* *}$ & 1 & $0.712^{*}$ \\
$\begin{array}{l}\text { Total Phenolic } \\
\text { Content }\end{array}$ & $0.814^{* *}$ & $0.712^{*}$ & 1 \\
\hline
\end{tabular}

**Correlation is significant at $\alpha<0.01$ (2-tailed); * Correlation is significant at $\alpha<0.05$ (2-tailed). 
In the present study, it was observed that using ABTS assay the antioxidant capacity of the spirit samples was consistent with total phenolic content (Tables II and IV). Similar results were observed for fruit liquor samples (Tables III and V).

In addition, in the present study a greater correlation between total phenolic content and ABTS assay than with DPPH assay was found. On the other hand, when the correlation between antioxidant capacities measured by ABTS, DPPH and total phenolic content in spirits was determined a weak correlation was found, between antioxidant capacity evaluated by ABTS and DPPH methods $(r=0.023)$ and DPPH antioxidant activity and total phenolic content $(\mathrm{r}=$ 0.239), evaluated by Folin-Ciocalteu method. Antioxidant activity determined using ABTS assay had a slightly better and significant correlation with total phenolic content $(r=0.448 ; \alpha<0.05)$.

Towards fruit liquors (Table V), a Spearman-Rho correlation coefficient of $r=0.883(\alpha<0.01)$ for the relationship between ABTS and DPPH assays was found. Additionally, the correlation between ABTS and total phenolic content was significantly high ( $\mathrm{r}=$ 0.814; $\alpha<0.01$ ) and stronger than the correlation between ABTS and total phenolic content ( $\mathrm{r}=0.712$; $\alpha<0.05$ ). These results suggest that in the case of fruit liquors both methods, ABTS and DPPH, are suitable to determine the total antioxidant capacity.

Hence, in this study, the total antioxidant capacity of the fruit liquors and spirits revealed a good correlation with the total content of phenols and, thus, these phenolic compounds seem to be responsible for the antioxidant potential of the samples. Furthermore, our results suggest that, in agreement with Floegel et al. (2011), who studied fruits, vegetables and beverages (fruit juices, tea, beer and table wine), the ABTS assay provides a better antioxidant capacity estimate in spirits than the DPPH assay. Based on these results, the evaluation of antioxidant activity of several spirits, including spirits from Arbutus unedo L. fruits, using ABTS method, is an ongoing work that will be released in a further publication.

In the future, it would be desirable to expand the total antioxidant capacity and total phenolic compounds evaluation, using ABTS and Folin-Ciocalteu assays, to as many alcoholic fruit beverages as possible, with the objective of building a database and making this information widespread.

\section{CONCLUSIONS}

The antioxidant capacity of fruit liquors and spirits, sourced commercially or produced on a pilot-scale, was assessed using two simple spectrophotometric methods, ABTS and DPPH assays. Furthermore, the total phenolic compounds of both kinds of alcoholic beverages were determined by Folin-Ciocalteau method. A weak Spearman correlation coefficient ( $\mathrm{r}$ $=0.023$ ) between ABTS and DPPH methods in spirits were found, as well as, between DPPH values and total phenolic compounds content $(r=0.239)$. This work emphasises the limitations of DPPH assay when used for analysis of samples such as distilled spirits with very low total antioxidant capacity.

\section{ACKNOWLEDGMENTS}

To Fundação para a Ciência e a Tecnologia (FCT), project - PTDC/AGR-FOR/3746/2012, “Arbutus unedo plants and products quality improvement for the agro-forest sector" and PEstOE/AGR/UI4033/2014, for CITAB. The authors thank Angela Carvalho (Jersey City, NJ, USA) for her proofreading of the English manuscript, and Amelia Soares and Deolinda Mota for their technical support.

\section{REFERENCES}

Ancerewicz J., Miglavaca E., Carrupt P.A., Testa B., Bree F., Zinin R., Tillement J.P., Labidelle P., Goyot S.D., Chauvet-Monges A.M., Crevent A., Le Ridant A., 1998. Structure property relationship of trimetadizine derivatives and model compounds as potential antioxidants. Free Rad. Biol. Med., 25, 113-120.

Aoshima H., Tsunoue H., Koda H., Kiso Y., 2004. Aging of whiskey increases 1,1-diphenyl-2-picrylhydrazyl radical scavenging Activity. J. Agric. Food Chem., 52, 5240-5244.

Arnous A., Makris D.P., Kefalas P., 2001. Effect of principal polyphenolic components in relation to antioxidant characteristics of aged red wines. J. Agric. Food Chem., 49, 5736-5742.

Blois M.S., 1958. Antioxidant determinations by the use of a stable free radical. Nature, 18, 1199-1200.

Brand-Williams W., Cuvelier M.E., Berset C., 1995. Use of a free radical method to evaluate antioxidant activity. Food Sci. Technol., 28, 25-30.

Canas S., 2003. Study of the extractable compounds of woods (oak and chestnut) and the extraction processes in the enological perspective. 303 p. Tese de Doutoramento, Instituto Superior de Agronomia, Universidade Técnica de Lisboa.

Canas S., Casanova V., Belchior P., 2008. Antioxidant activity and phenolic content of Portuguese wine aged brandies. J. Food Compos. Anal., 21, 626-633.

Céspedes C.L., Valdez-Morales M., Avila J.G., El-Hafidi M., Alarcón J., Paredes-López O., 2010. Phytochemical profile and the antioxidant activity of Chilean wild black-berry fruits, Aristotelia chilensis (Mol) Stuntz (Elaeocarpaceae). Food Chem., 119, 886895.

Da Porto C., Calligaris S., Celotti E., Nicoli M.C., 2000. Antiradical properties of commercial cognacs assessed by the DPPH test. J. Agric. Food Chem., 48, 4241-4245.

Da Silva A.A., Nascimento E.S., Cardoso D.R., Franco D.W., 2009. Coumarins and phenolic fingerprints of oak and Brazilian wood extracted by sugarcane spirit. J. Sep. Sci., 32, 3681-3691.

De Aquino F.W.B., Rodrigues S., Nascimento R.F., Casimiro A.R.S., 2006. Simultaneous determination of aging markers in sugar cane spirits. Food Chem., 98, 569-574.

Dudonné S., Vitrac X., Coutière P., Woillez M., Mérillon J..M., 2009. Comparative study of antioxidant properties and total phenolic content of 30 plant extracts of industrial interest using DPPH, ABTS, FRAP, SOD, and ORAC assays. J. Agric. Food Chem., 57, 1768-1774.

Floegel A., Kim D.-O., Chung S.-J., Koo S.I., Chun O.K., 2011. Comparison of ABTS/DPPH assays to measure antioxidant 
capacity in popular antioxidant-rich US foods. J. Food Compos. Anal., 24, 1043-1048.

Gardner P.T., White T.A.C., McPhail D.B., Duthie G.G., 2000. The relative contributions of vitamin $\mathrm{C}$, carotenoids and phenolics to the antioxidant potential of fruit juices. Food Chem., 50, 471-474.

Giacco F., Brownlee M., 2011. Oxidative stress and diabetic complications. Circulation Research, 107, 1058-1070.

Goldberg D.M., Hoffman B., Yang J., Soleas G., 1999. Phenolic constituents, furans and total antioxidant status of distilled spirits. J. Agric. Food Chem., 47, 3978-3985.

Gorinstein S., Haruenkit R., Poovarodom S., Vearasilp S., Ruamsuke P., Namiesnik J., Leontowicz M., Leontowicz H., Suhaj M., Sheng G.P., 2010. Some analytical assays for the determination of bioactivity of exotic fruits. Phytochem. Anal., 21, 355-362.

Halliwell B., 1994. Free radicals, antioxidants, and human disease: curiosity, cause, or consequence? The Lancet, 344, 721-724.

Huang W., Zhang H., Liu W., Li C., 2012. Survey of antioxidant capacity and phenolic composition of blueberry, blackberry, and strawberry in Nanjing. J. Zhejiang University - SCIENCE B, 13, 94-102.

Kim D.-O., Lee K.W., Lee H.J., Lee C.Y., 2002. Vitamin C equivalent antioxidant capacity (VCEAC) of phenolic phytochemicals. J. Agric. Food Chem., 50, 3713-3717

Liu M., Li X.Q., Weber C., Lee C.Y., Brown J., Liu R.H., 2002. Antioxidant and antiproliferative activities of raspberries. J. Agric. Food Chem., 50, 2926-2930.

Macheix J.J., Fleuriet A., Billot J., 1990. Fruit Phenolics. CRC Press, Boca Raton, FL.

Madrera R.R., Gomis D.B., Alonso, J.J.M., 2003. Influence of distillation system, oak wood type and aging time composition of cider brandy in phenolic and furanic compounds. J. Agric. Food. Chem., 51, 7969-7973.

Miller N., Rice-Evans C., 1997. Factors influencing the antioxidant activity determined by the ABTS radical cation assay. Free Radical Res., 26, 195-199.
Molyneux F., 2004. The use of the stable free radical diphenylpicrylhydrazyl (DPPH) for estimating antioxidant activity. Songklanakarin J. Sci. Technol., 26, 211-219.

Mosedale J.R., Puech J.L., 1998. Wood maturation of distilled beverages. Trends Food Sci. Technol., 9, 95-101.

Mrvcic J., Sanja Posavec S., Kazazic S., Stanzer D., Peša A., Stehlik-Tomas V., 2012. Spirit drinks: a source of dietary polyphenols. Croat. J. Food Sci. Technol., 4, 102-111.

OIV, 2014. Compendium of International Methods of Spirituous Beverages of Vitivinicultural Origin. OIV, Paris.

Oliveira A.C., Valentim I.B., Goulart M.O., 2009. Vegetables as natural sources of antioxidants. Química Nova, 32, 689-702.

Ratnam V.D., Ankola D.D., Bhardwaj V., Sahana D.K., Kumar R.M.N.V., 2006. Role of antioxidants in prophylaxis and therapy: a pharmaceutical perspective. J. Controlled Release, 113, 189-207.

Regulation EC n. 110/2008 of the European parliament and of the council of 15 January 2008 on the definition, description, presentation, labelling and the protection of geographical indications of spirit drinks and repealing Council Regulation (EEC) No 1576/89 Official Journal of the European Communities, L39, 16-54.

Sharma O.P., Bhat T.K., 2009. DPPH antioxidant assay revisited. Food Chem., 113, 1202-1205.

Singleton V.L., Rossi J.A., 1965. Colorimetry of total phenolics with phosphomolybdic-phosphotungstic acid reagents. Am. J. Enol. Vitic., 16, 144-158.

Valko M., Rhodes C.J., Moncol J., Izakovic M., Mazur M., 2006. Free radicals, metals and antioxidants in oxidative stress-induced cancer. Chemico-Biological Interactions, 160, 1-40.

Vicente C.D., De Abreu F.C., Goulart M.O.F., De Vasconcelos J.N., 2011. Phenolic constituents, furfuraldehyde and capacity of sugar cane spirit aged in woods casks. Am. J. Food Tech., 6, 631646.

Viriot C., Scalbert A., Lapierre C., Moutounet M., 1993. Ellagitannins and lignins in aging of spirits in oak barrels. J. Agric. Food Chem., 41, 1872-1879. 